\title{
SALA EDI BALOD EM HOME OFFICE
}

Daniele Cristina Zacarão Pereira

Bruna Speck da Silva

\section{DOI: http://dx.doi.org/10.18616/intcov32}

A Sala Edi Balod - Espaço de Exposições e Laboratório de Artes Visuais é um equipamento cultural localizado na Universidade do Extremo Sul Catarinense (UNESC). Vinculada aos cursos de Artes Visuais e Teatro da UNESC, a Sala Edi Balod configura-se como um laboratório que possibilita aos acadêmicos, experiências com criação, produção, expografia, curadoria e mediação cultural. Além das atividades ligadas às disciplinas, o espaço também mantém a prática de promover oficinas, palestras, ateliês temporários, sessões de cinema, grupo de estudos e atividades de intercâmbio com artistas e pesquisadores de outras regiões. Porém, como medida de prevenção à covid-19, todas as atividades planejadas para o ano de 2020 foram temporariamente suspensas, e ainda permanecem sem perspectiva de retorno.

O Projeto Sala Edi Balod em Home Office surge para dar continuidade ao trabalho e manter o contato com o seu público, a partir de uma programação proposta por professores e acadêmicos dos cursos de Arte Visuais e Teatro, adotando diferentes formatos via plataformas digitais, como:

Visita ao Ateliê: atividade que convida artistas a produzirem vídeos apresentando seu espaço de criação e processos artísticos durante o período de isolamento social. Até o momento sete artistas participaram dessa ação disponibilizada nas plataformas digitais Instagram e YouTube.

Curadoria Doméstica: uma exposição coletiva no espaço das redes sociais, ativada pelo uso da hashtag \#curadoriadoméstica. A proposta contempla trabalhos produzidos a partir de situações, ações, proposições e/ou intervenções no espaço doméstico.

Sala de Cinema: um cineclube que foi adaptado para o formato on-line, e que cada participante assiste ao filme em sua casa e despois participa de um debate coletivo, via videoconferência. 
Leitura Dramatizada: experiência realizada pelo curso de Teatro, por meio de videoconferência, na qual os acadêmicos apresentaram ao público a leitura dramática da peça Nau dos Loucos, de Luís Alberto de Abreu, dividida em duas sessões, no formato das antigas radionovelas. A gravação das duas apresentações está disponível no YouTube.

Lançamento de Catálogos: publicação de catálogos das atividades realizadas em 2016 e 2017, os dois primeiros anos de atuação da Sala Edi Balod. Os catálogos foram lançados via vídeo na programação dos 52 anos da UNESC; atualmente, estão disponíveis em e-book para visualização e download no site da Sala Edi Balod.

Aulas Abertas: são aulas de disciplinas do curso de Artes Visuais abertas ao público, por meio de videoconferência, com a participação de artistas e/ou pesquisadores convidados.

No atual contexto, foi necessário criar novos formatos e espacialidades para que os equipamentos culturais se mantivessem ativos e que suas práticas chegassem até o público, em casa. Uma programação para o formato virtual não significa apenas adaptar práticas do espaço físico, mas principalmente, criar conteúdo, apropriar-se desse novo espaço, considerando suas especificidades e potencialidades. Nesse sentido, as experiências realizadas pela Sala Edi Balod em home office podem ser compreendidas como um importante laboratório de gestão cultural, que nos ajuda a pensar a atuação dos espaços de cultura durante e pós-pandemia. 